\title{
Flavonol Robinobiosides and Rutinosides from Alternanthera brasiliana (Amaranthaceae) and their Effects on Lymphocyte Proliferation In Vitro
}

\author{
Claudia de O. Brochado ${ }^{a}$, Ana P. de Almeida ${ }^{a}$, Beatriz P. Barreto ${ }^{a}$, Leandro P. Costa ${ }^{a}$, \\ Luciene S. Ribeiro ${ }^{a}$, Rachel L. da C. Pereira ${ }^{b}$, Vera L. Gonçalves Koatz ${ }^{b}$ and Sonia S. Costa*,a \\ ${ }^{a}$ Núcleo de Pesquisas de Produtos Naturais, Universidade Federal do Rio de Janeiro, 21941-590 \\ Rio de Janeiro - RJ, Brazil \\ ${ }^{b}$ Departamento de Bioquímica Médica, Instituto de Ciências Biomédicas, Universidade Federal do Rio de Janeiro, \\ 21941-590 Rio de Janeiro - RJ, Brazil
}

\begin{abstract}
O extrato da espécie medicinal Alternanthera brasiliana Kuntze forneceu seis derivados di- e triglicosilados de kaempferol e quercetina. As estruturas foram elucidadas com base em $\mathrm{RMN}$ de ${ }^{1} \mathrm{H}$ $\mathrm{e}^{13} \mathrm{C}$. Os seis flavonóides são inéditos no gênero. Kaempferol 3-O-robinobiosídeo e kaempferol 3$O$-rutinosídeo inibiram mais eficientemente a proliferação de linfócitos humanos in vitro.
\end{abstract}

The extract of the medicinal species Alternanthera brasiliana Kuntze afforded six di- and triglycosyl kaempferol and quercetin derivatives. Their structures were elucidated based on the ${ }^{1} \mathrm{H}-$ and ${ }^{13} \mathrm{C}-\mathrm{NMR}$ data and are reported here for the first time in this genus. Kaempferol 3-O-robinobioside and kaempferol 3-O-rutinoside significantly inhibited the human lymphocyte proliferation in vitro.

Keywords: Alternanthera brasiliana, Amaranthaceae, flavonol robinobiosides, flavonol rutinosides, lymphocyte proliferation

\section{Introduction}

Alternanthera brasiliana Kuntze (Amaranthaceae) is a herbaceous plant used against inflammation, cough and diarrhoea in Brazilian popular medicine. ${ }^{1}$ In a search for some action of this plant against inflammatory cells of the immune system, it was shown that aqueous or ethanolic $A$. brasiliana leaf extracts are able to block human mitogeninduced lymphocyte proliferation, without any toxic effect. ${ }^{2}$ Different biological activities have been established for A. brasiliana species; ${ }^{2-4}$ however, this is the first chemical study of its secondary metabolites.

\section{Results and Discussion}

Bioassay-guided fractionation of a water-soluble phase of an ethanolic leaf extract (EE) was carried out with the aim of identifying compounds responsible for the antiproliferative effect of the crude extract on lymphocytes.

Six flavonoids were identified: kaempferol 3-Orobinobioside-7- $O$ - $\alpha$-L-rhamnopyranoside or robinin (1),

* e-mail: sscosta@nppn.ufrj.br quercetin 3-O-robinobioside-7- $O$ - $\alpha$-L-rhamnopyranoside or clovin (2), quercetin 3-O-robinobioside (3), kaempferol 3-O-robinobioside (4), kaempferol 3-O-rutinoside-7- $O-\alpha$ L-rhamnopyranoside (5) and kaempferol 3-O-rutinoside (6). Their structures were elucidated by ${ }^{1} \mathrm{H}$ - and ${ }^{13} \mathrm{C}-\mathrm{NMR}$ data $\left({ }^{1} \mathrm{H}-{ }^{1} \mathrm{H}\right.$ COSY, APT, HETCOR $)$ and agree with literature data. $^{5-9}$

A. brasiliana contains mainly 3-O-robinobioside derivatives of kaempferol and quercetin. The kaempferol skeleton was present in four of the six flavonoids isolated. Additional glycosylation was observed at C-7 for 1, 2 and 5. Only two flavonoids $(\mathbf{5}, \mathbf{6})$ showed a rutinosyl instead of a robinobiosyl moiety at $\mathrm{C}-3$. These results demonstrate that the $1 \rightarrow 6$ galactopyranosyl-rhamnopyranosyl linkage is prevalent among the A. brasiliana flavonol glycosides. To the best of our knowledge, the two glycosyl flavones isolated from A. phyloxeroides are the only flavonoids previously reported for this genus. ${ }^{10,11}$

Although not widespread in nature, flavonol robinobiosides have been isolated from different plant species, particularly Strychnos variabilis. ${ }^{9,12-13}$ Recently two spinacetin robinobioside derivatives, one of them belonging to the unusual class of methylene bisflavonoids, 
were described from Blutaparon portulacoides, another medicinal species of Amaranthaceae. ${ }^{14}$

Flavonoids 1-6 are reported here for the first time for Alternanthera. Kaempferol 3-O-robinobioside (4) and 3$O$-rutinoside (6) inhibited lymphocyte proliferation to a greater extent $\left(\mathrm{IC}_{50} \cong 25 \mu \mathrm{g} \mathrm{mL}^{-1}\right)$ and were twice as active as the crude extract (Table 1). The anti-inflammatory effects ${ }^{15}$ observed in vivo can be attributed to the effects of these flavonoids on T-cell function, thereby accounting for the medicinal properties of A. brasiliana.

Table 1. Inhibition of the in vitro proliferative response of human T-cells by A. brasiliana extract (WE) and its flavonoids 1-6

\begin{tabular}{cc}
\hline Sample & $\mathrm{IC}_{50}\left(\mu \mathrm{g} \mathrm{mL}^{-1}\right)$ \\
\hline WE & 50 \\
1 & 50 \\
2 & 50 \\
3 & 50 \\
$\mathbf{4}$ & $\mathbf{2 5}$ \\
5 & 100 \\
$\mathbf{6}$ & $\mathbf{2 5}$ \\
Azathioprine $^{\mathrm{a}}$ & 0.2 \\
\hline
\end{tabular}

$\mathrm{WE}=$ water-soluble extract; ${ }^{a}$ positive control.

\section{Experimental}

\section{General}

${ }^{1} \mathrm{H}$ - and ${ }^{13} \mathrm{C}$-NMR spectra (DMSO- $d_{6}$ signals as internal reference: $\delta$ 2.49) were recorded on a Varian Gemini 200 $\left({ }^{1} \mathrm{H}: 200 \mathrm{MHz} ;{ }^{13} \mathrm{C}: 50 \mathrm{MHz}\right)$ or in a Bruker DRX-400 $\left({ }^{1} \mathrm{H}-, 400 \mathrm{MHz} ;{ }^{13} \mathrm{C}-, 100 \mathrm{MHz}\right) .[\alpha]_{\mathrm{D}}$ was measured in a Perkin-Elmer 243B polarimeter; and melting points were obtained using a Kofler apparatus. Reversed-phase chromatography was performed on RP-2 or RP-8 silanized silica (Merck) and size exclusion chromatography on Sephadex LH-20 (Sigma). Eluates were monitored by thinlayer chromatography on Silica $60 \mathrm{~F}_{254}$ (Merck) using butanol-acetic acid-water (8:1:1) for development and ceric sulfate solution as detection reagent.

\section{Plant material}

A. brasiliana was collected out of flowering season on the University (UFRJ) campus (Ilha do Fundão). A voucher specimen (RFA-25 052) was deposited in the herbarium of the Department of Botany (Instituto de Biologia, UFRJ, Brazil).

\section{Extraction and isolation}

Fresh purple leaves $(2.06 \mathrm{Kg})$ were macerated with ethanol for a week in the dark. The resulting ethanolic extract afforded a syrupy dark material (EE, 66.1 g) which was washed with distilled water. The water-soluble extract (WE) was lyophilised (28.3 g), re-suspended in water and chromatographed on an RP-2 column with a water/ methanol gradient (19 fractions). Four major flavonoid fractions were obtained $\left(\mathrm{H}_{2} \mathrm{O}: \mathrm{MeOH}\right.$ ration in parenthesis): F and $\mathrm{G}(7: 3) ; \mathrm{H}$ (7:3 to $1: 1)$ and $\mathrm{J}(1: 1)$. Flavonoids 1 and 2 were obtained from fraction $\mathrm{F}(453 \mathrm{mg})$ by successive Sephadex LH-20 chromatography (EtOH). Crude 1 (36 mg) was crystallised from ethanol to give pure $\mathbf{1}$ as a lightyellow solid (27.4 mg), $\mathrm{R} f$ 0.22: $\mathrm{mp} 185-187{ }^{\circ} \mathrm{C}$; ${ }^{1} \mathrm{H}$ - and ${ }^{13} \mathrm{C}-\mathrm{NMR}$ as described before. ${ }^{5}$ After elution of $\mathbf{1}$, flavonoid 2 was obtained from the same column as a light-yellow powder (25.5 mg), Rf 0.18: mp 195-200 ${ }^{\circ} \mathrm{C} ;[\alpha]_{\mathrm{D}}-66^{\circ}$ (c $0.5, \mathrm{EtOH}) ;{ }^{1} \mathrm{H}$ and ${ }^{13} \mathrm{C}-\mathrm{NMR}$ as described before. ${ }^{6}$ Concentration of fraction $\mathrm{G}$ yielded a precipitate $(153 \mathrm{mg})$ which was separated by centrifugation. A sample (72 mg) was chromatographed on an RP-2 column $\left(\mathrm{H}_{2} \mathrm{O}: \mathrm{MeOH}\right.$ 8:2 to $\mathrm{MeOH} 100 \%$ ) to obtain flavonoid 5 (yellow powder, 35 $\mathrm{mg}, \mathrm{Rf}$ 0.28): $\mathrm{mp}$ 195-200 ${ }^{\circ} \mathrm{C},{ }^{1} \mathrm{H}$ - and ${ }^{13} \mathrm{C}-\mathrm{NMR}$ as described before. ${ }^{7,8}$ The supernatant $(826 \mathrm{mg})$ of fraction $\mathrm{G}$ yielded a crude precipitate $(219 \mathrm{mg}$ ) which was dissolved in distilled water, and $\mathbf{3}$ was obtained by freezing and thawing the resulting aqueous solution (yellow powder,

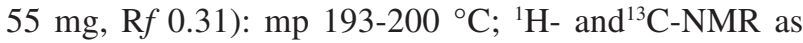
described before. ${ }^{9}$ Fraction $\mathrm{H}$ (551 mg) was washed with acetone. Concentration of the acetone-soluble phase gave a precipitate $(242 \mathrm{mg}$ ) that was purified as described for $\mathbf{3}$ to obtain pure 4 (yellow powder, $57 \mathrm{mg}$, Rf 0.35 ): $\mathrm{mp} 175$ $180{ }^{\circ} \mathrm{C} ;{ }^{1} \mathrm{H}$ and ${ }^{13} \mathrm{C}-\mathrm{NMR}$ as reported before. ${ }^{9}$ The ethanolsoluble phase of fraction $\mathrm{J}$ (484 mg) gave a yellow material (364 mg) which was chromatographed on Sephadex LH20 (EtOH, 7 fractions). Fraction 2 (33 mg) was dissolved in $\mathrm{MeOH}: \mathrm{H}_{2} \mathrm{O}$ 3:7 and purified on an RP-8 column. The fraction eluted with $50 \% \mathrm{MeOH}$ gave flavonoid 6 (yellow crystals, $2.8 \mathrm{mg}, \mathrm{R} f$ 0.38): $\mathrm{mp} 178{ }^{\circ} \mathrm{C} ;[\alpha]_{\mathrm{D}}+10.0$ (c 0.2 , $\left.\mathrm{H}_{2} \mathrm{O}\right) ;{ }^{1} \mathrm{H}$-and ${ }^{13} \mathrm{C}$-NMR as already reported. ${ }^{7,8}$

\section{Lymphocyte proliferation assay}

Human peripheral blood mononuclear cells (PBMC) were obtained from healthy volunteers by Ficoll-Hypaque density gradient centrifugation. Cells $\left(10^{6}\right.$ cells $\left.\mathrm{mL}^{-1}\right)$ were cultivated in the presence of $5 \mu \mathrm{g} \mathrm{mL}^{-1}$ phytohemagglutinin (PHA) at $37{ }^{\circ} \mathrm{C}$ and $5 \% \mathrm{CO}_{2}$. Dose-response curves were obtained by adding different concentrations of extract, flavonoids and azathioprine to triplicate samples, and inhibition was expressed as $\mathrm{IC}_{50}$. Proliferation was measured by $\left[{ }^{3} \mathrm{H}\right]$ thymidine incorporation into cellular DNA: 0.5 $\mu \mathrm{Ci} /$ well was added $6 \mathrm{~h}$ before the end of the culture period 
(96 h). Cells were harvested and the radioactivity assessed using a liquid scintillation counter. In controls with PHA alone, proliferation of $42550 \pm 1300 \mathrm{cpm}$.

\section{Acknowledgements}

We thank E. Miguez (NPPN, UFRJ) for the NMR spectra, Dr. J. Rabi (Microbiologica, Brazil) for the gift of azathioprine and Dr Martha M. Sorenson (Depto de Bioquímica Médica, ICB, UFRJ) for the careful revision of the manuscript. CNPq-PIBIC, CNPq, FINEP, FAPERJ and FUJB (Brazil) supported this work.

\section{References}

1. Di Stasi, L.C.; Hiruma, C.A.; Guimarães, E.M.; Santos, C.M.; Fitoterapia 1994, LXV, 529.

2. Moraes, V.L.G.; Santos, L.F.M.; Castro, S.B.; Loureiro, L.H.; Lima, O.A.; Souza, M.L.M.; Yien L.M.K.; Rossi-Bergmann, B.; Costa, S.S.; Phytomedicine 1994, 1, 199.

3. Lagrota, M.H.C.; Wigg, M.D.; Santos, M.M.G.; Miranda, M.M.F.S.; Camara, F.P.; Couceiro, J.N.S.S.; Costa, S.S.; Phytother. Res. 1994, 8, 358.
4. De Souza, M.M.; Kern, P.; Floriani, A.E.O.; Cechinel, V.; Phytother. Res. 1998; 12, 279.

5. Wenkert, E.; Gottlieb, H.E.; Phytochemistry 1977, 16, 1811.

6. Schaufelberger, D.; Gupta, M.P.; Hostettmann, K.; Phytochemistry 1987, 26, 2377.

7. Aly, H-F.; Geiger, H.; Schücker, U.; Waldrum, H.; Vander Velde, G.; Mabry, T.J.; Phytochemistry 1975, 14, 1613.

8. Markham, K.R.; Ternai, B.; Stanley, R.; Geiger, H.; Mabry, T.J.; Tetrahedron 1978, 34, 1389.

9. Brasseur, T.; Angenot, L.; Phytochemistry 1986, 25, 563.

10. Zielske, A.G.; Simons, J.N.; Silverstein, R.M.; Phytochemistry 1972, 11, 393.

11. Zhou, B.N.; Blasko, G.; Cordell, G.A.; Phytochemistry 1988 , 27, 3633.

12. Brasseur, T.; Angenot, L.; Phytochemistry 1987, 26, 3331.

13. Brasseur, T.; Angenot, L.; Phytochemistry 1988, 27, 1487.

14. De Oliveira, D.B.; MSc. Thesis, Universidade Federal do Rio de Janeiro, Brazil, 2001.

15. Middleton Jr., E.; Kandaswami, C.; Theoharides T.C.; Pharmacol. Rev. 2000, 52, 673.

Received: April 4, 2002

Published on the web: March 24, 2003 